\title{
EMPOWERING LEADERSHIP AND TEAM CREATIVITY: UNDERSTANDING THE DIRECT-INDIRECT PATH
}

\author{
Ahmad ADEEL ${ }^{1}$, Samreen BATOOL ${ }^{2}$, Rizwan ALI $^{3}$ \\ ${ }^{1}$ Lahore Business School, The University of Lahore, Gujrat Campus, Pakistan \\ ${ }^{2}$ Huazhong University of Science and Technology, Wuhan, China \\ ${ }^{3}$ Lahore Business School, The University of Lahore, Lahore, Pakistan \\ E-mails: ${ }^{1}$ ahmad.adeel@lbs.uol.edu.pk; ${ }^{2}$ samreenleads@yahoo.com; \\ ${ }^{3}$ rizwan.ali@lbs.uol.edu.pk (correspondingauthor)
}

Received 19 May 2018; accepted 29 September 2018

\begin{abstract}
This study investigated the relationship between empowering leadership and team creativity by integrating the theory of group behavior with componential theory of creativity. For this study, data was collected from two sources ( 343 Subordinates, 67 Supervisors) by temporally dividing data collection process into two points in time for independent, dependent, and mediating variables from employees of a bank operating in Pakistan. Random coefficient analysis technique was used with Mplus 7.0 to analyze nested data for preliminary analysis and analysis of mediation and indirect effects. Mediation was analyzed using the indirect effect of random models and further confirmed the confidence using bootstrapping procedure. Through this study, the researchers tried to explore the inconsistent relationship between empowering leadership behavior and team creativity. It was found that empowering leadership behavior affects the team level creativity of employees directly and indirectly through the mediation of team learning behavior and team psychological empowerment as team process and team emergent states respectively. The results indicated that empowering leadership enhances the learning potential of teams and team empowerment perception which in turn enhances team level creativity. Further research findings, implications, and future research directions also discussed in this research.
\end{abstract}

Keywords: empowering leadership, team learning behavior, psychological empowerment, team creativity.

JEL Classification: M54, J2, C92.

\section{Introduction}

In the contemporary, dynamic, and competitive marketplace, organizations need to exploit their potential to enhance their ability to produce more creative solutions for survival (e.g., Erdogan et al. 2015, Cho and Pucik 2005). Organizational innovative outputs are consistently linked with a higher rate of their growth, sustainability, and profitability (e.g., Subramaniam and Youndt 2005). Given its practical importance, researchers have largely investigated the factors which can affect and contribute to the creativity of the employees. Team level research of creativity suggested that individuals in teams bring diversified knowledge, skills, and expertise to produce more creative solutions (e.g., Taggar 2001, Zhou and George 2003). The diversified knowledge and expertise which team members bring forward for the team enhance their overall divergent thinking and flexible problem solving (Granovetter et al. 1982).

Leaders' behavior is one of the most investigated behaviors in creativity research; researchers found that leaders can affect the potential of individuals and teams for creativity (e.g., Druskat and Wheeler 2003, D'Innocenzo et al. 2016, DeConinck and DeConinck 2017, Ng 2017). Among these studied behaviors, empowering leadership behavior has been given special attention in management literature. This behavior is closely related to the recent trend of providing autonomy to the organizational employees (Lawler et al. 2001, Chamberlin et al. 2018). Equivocal results found in literature about the relationship between empowering leadership and creativity of employees (e.g., Zhang et al.

Copyright $\odot 2018$ The Authors. Published by VGTU Press.

This is an Open Access article distributed under the terms of the Creative Commons Attribution License (http://creativecommons.org/licenses/by/4.0/), which permits unrestricted use, distribution, and reproduction in any medium, provided the original author and source are credited.. 
2018). Researchers found that empowering leadership positively affects the creativity of the employee by enhancing the sense of autonomy among employees (Chow 2018). Contrary, some researchers questioned this link and found that empowering leadership behavior can hamper creativity of the employees and organizational innovative potential (e.g., Amabile et al. 2014) by inducing inner friction and can negatively affect the exchange of novel and useful ideas (e.g., Lawler et al. 2001, Van knippenberg et al. 2004). A dilemma result, empowering leadership behavior which fosters creativity of the teams by providing autonomy to the employees, on the other hand, hampers the exchange of creative ideas.

Therefore, it is important to investigate the relationship between empowering leadership behavior as structural empowerment property and team level creativity of employees. In this research building on the framework of the theory of group behavior (Wegner 1987) and componential theory of creativity (Amabile 1996), we proposed here that empowering leadership behavior as an important factor to foster the creativity of work teams by affecting the learning behavior of the teams and team psychological empowerment. We are likely to contribute to management literature in several ways. First, the most important implication for the theory is investigating the direct relationship of empowering leadership on team creativity. Empowering leadership is a form of structural empowering behavior (Liden et al. 2000) which was long conceptualized as having effect on performance-related outcomes on both individual and team levels (Chang and Chuang 2011, Ahearn et al. 2004), but team level investigations are very limited to empirically prove the relationship between empowering leadership as structural empowering behavior of leaders to their subordinates, in this research the researchers reinvestigated the direct impact of empowering leadership behavior on team level creativity of the employees.

Second, creativity is an important property of performance for the survival and existence of organizations in this contemporary dynamic environment (Shalley et al. 2004). In this research this recent trend in management studies captured by investigating creativity of teams as an important determinant of performance (e.g., Carnabuci and Diószegi 2015, Chen et al. 2015, Venkataramani et al. 2016). Finally, leaders' role was conceptualized and found to affect the creativity of employees (e.g., Chen et al. 2015, Zhou et al. 2009). Two major perspectives have been used by previous researchers while investigating empowering leadership behavior. First, leaders' willingness to share power, increase responsibilities of employees, and autonomy in decisions and actions of employees (Chang and Chuang 2011), second, the response of employees to empowerment specifically, investigating motivation of employees in response to empowerment (Chang and Chuang 2011). With few exceptions, these two perspectives have rarely been investigated in

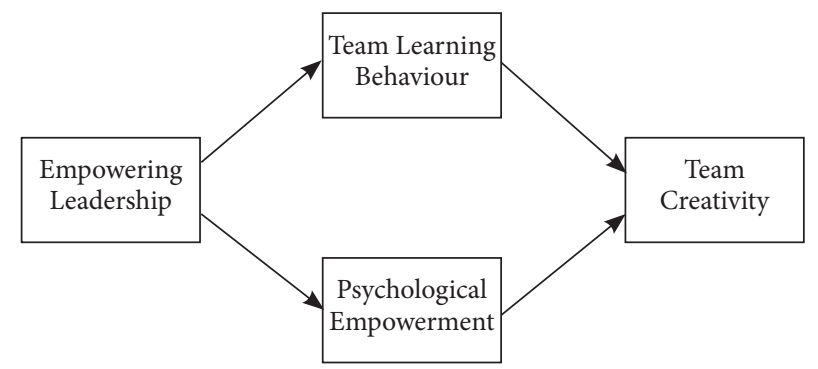

Figure 1. Research model

one empirical investigation (e.g., Srivastava et al. 2006). In this research, these two perspectives of empowerment have been integrated to understand the mechanisms through which empowering leadership behavior might influence team creativity at organizations. Graphical representations of hypothesized relationships are depicted in Figure 1.

\section{Literature review and hypothesis}

\subsection{Relationship between empowering leadership behavior and learning behavior of teams}

Empowering leadership behavior is closely related to recent trend at organizations in empowering their workforce to enhance their performance (Lawler et al. 2001, DeConinck and DeConinck 2017). The purpose of this line of research remained with understating two important aspects here, one leaders role in sharing his/ her authority and independence of subordinates (Lawler et al. 2001) and on other end, subordinates' response towards this empowerment behavior (Spreitzer 2008, Lawler et al. 2001) but in these research lines, these two perspectives have been investigated independently, investigating both lines of research in one investigation is very rare (e.g., Bunderson and Sutcliffe 2003). In this research, the researchers tried to investigate these relationships in a single study, more specifically the researchers investigated leaders' empowering behavior and employee's response towards these empowerment behaviors in a single investigation which have rarely been investigated previously (Srivastava et al. 2006).

Team learning behavior, a behavior of team to collectively participate in thoughtful decision making, questioning for learning, seeking advice for improvements, and arguing mistakes for further improvements (Edmondson 1999). Team learning behavior was positively related to creativity at organizations (Hirst et al. 2009, Li et al. 2018). Team learning behavior is different from other behavior of the teams like "team climate" and "shared learning orientations" because we not collective belief of team members (Katz and Kahn 1978) or the motivational aspects of team learning orientations with encourage mutual learning (Srivastava et al. 2006, Dong et al. 2017), we procedure through which member of the teams learn to resolve issues by discussing. Teams when the search for knowledge, discuss diversity in their opinions and question the offered solutions are 
called involved in studying behaviors (Spreitzer 2008). Team learning behavior cannot be guaranteed to bring forth good benefits from the network, attract better financial resources and funding, rather it promotes mutual information seeking for problem-solving as a team process.

Consequently, overall knowledge and information of teams increase by creating an environment where team members easily learn by eliminating any psychological risk attached with learning, this also encourages people to learn mutually on an ongoing basis and solve problems effectively by initiating social learning process (Rosenthal and Zimmerman 1978). Knowledge and information exchange are important tenants of team learning behavior. But this information and knowledge sharing is not a self-ignited process which starts automatically with work units. Team leaders have an important role in sharing knowledge and information beneficial for the teams. Empowering leadership encourages employees to share knowledge and seek for the information (Bunderson and Sutcliffe 2003, Mathieu et al. 2017) beneficial for collective learning behavior (Srivastava et al. 2006). Supportive leaders (a basic trait of empowering leadership) are beneficial for mutual sharing and knowledge of employees by supporting them, guiding them, recognizing their valuable efforts, and treating them fairly (House and Dessler 1975). Therefore, building on all above arguments, this is expected that empowering leadership will promote team learning behavior. Formally:

Hypothesis 1: Empowering leadership relates positively to team learning behavior.

\subsection{Relationship between empowering leadership behavior and team psychological empowerment}

Leadership behaviors which promote power-sharing, influence intrinsic motivation of employees also enhance their self-efficacy (Locke et al. 1997). Feeling about psychological empowerment is a state when individuals and teams perceive that they organize and own work (e.g., Spreitzer et al. 2015) which is different from empowering leadership (e.g., Spreitzer 2008, Mills and Ungson 2003). Psychological empowerment mainly focuses on the employee cognition and perception of empowerment. The key to psychological empowerment is the belief of teams or individuals that they are well in position to perform and control their own work which is quite related with motivational processes (Conger and Kanungo 1988) of teams.

Taking two-dimensional perspectives, previous researchers suggested that, psychological empowerment is a perception about delegation of power and responsibilities in teams (Mathieu et al. 2000, Hechanova and Beehr 2001). However, researchers found that self-efficacy and independence are the main premises in psychological empowerment (Dvir et al. 2002). Leaders can affect team level psychological empowerment through different behaviors
(Aryee and Chen 2006, Dvir et al. 2002, Li et al. 2017). Leaders' guidance to employees for how to achieve goals and be effective increases their sense of responsibility and self-efficacy (Bandura 1997).

Participative decision making by formal leaders encourages employees to provide their input on the team decisions which in turn raise their sense of self-efficacy (Latham et al. 1994). Coaching behavior of formal leader encourages them to learn and grow by making them capable of doing independently, increase their sense of self-efficacy, independence, power, and responsibility. Researchers found that information about the direction of organization help individuals to set goals in line with organizations' objectives (Spreitzer 1995). Information to strategic goals, help employees to set their direction and actions (Kirkman and Rosen 1999), thereby enhancing their self-efficacy and sense of responsibility. Therefore, based on above discussion we can expect that empowering leadership behavior will promote psychological empowerment in teams. Formally:

Hypothesis 2: Empoweringleadership relates positively to team psychological empowerment.

\subsection{Relationship of team learning behavior and psychological empowerment with team creativity}

Team learning behavior may lead to better team creativity due to two main reasons: first, there is an improvement in decision making and second, there is an enhancement in inter employee coordination. Researchers found that enhanced team learning behavior lead to a more comprehensive understanding of teammates to consider the alternative in the more appropriate way and better utilize team knowledge resources for further decision making (Stasser and Titus 1985). Team learning behavior may also lead to improved team creativity at organizations by enhancing inter employee coordination, enhanced decision making in teams, and carefully choosing alternatives for any problem. Here, the researchers argue that team learning behavior will affect shared mental models and collective sharing of knowledge through knowledge management models specifically share mental models which ultimately will enhance inter employee coordination and growth in shared mental models.

These shared models are the collective memory systems of the organization. This is the social process through which employees share, store, enhance, and utilize knowledge stored in the social setting of employees at organizations (Mathieu et al. 2000). It is also critical to understand that holder of this knowledge is employees of the organizations. That is also a reason organization often engage employees in activities of knowledge exchange which ultimately bring the more specific tacit knowledge of employee which reside with the employee to bring and make it possible of other employees of the organizations. Timely sharing of information 
is related to enhanced performance and creativity at organizations (Kirkman and Rosen 1999). If members of the team develop and share information timely they actually develop a shared ability to utilize the shared resource of teams for further performance of the teams (Isenberg 1988). This can also help to develop a collective intuition of the team which may further help to enhance the performance of the team (Isenberg 1988). Thus, team learning behavior enhances the important ingredient of team level creativity: the knowledge resource of employees.

Team learning behavior may also be linked with collective efficacy which is an important predictor of employees' collective motivation. Team learning behavior can also help in the development of collective efforts of developing collective memory system which knows who knows what in teams (Wegner 1987). This collective effort of developing transaction memory system will also enhance a sense of collective caring for the task, the improved efficacy, enhance autonomy, and the influence for the outcomes (Spreitzer 1995) which may further relate to collective motivation of teammates. Collectively team learning behavior is related to improve team knowledge base and also the collective motivation of the team members which are ingredients of team level creativity at organizations. Therefore, the above arguments suggest that learning behavior of the team positively relate to creativity at team levels at organizations.

Hypothesis 3: Team learning behavior positively relates to team creativity.

\subsection{Relationship between psychological empowerment and team creativity}

Psychological empowered employees anticipate problems, act independently, face problems and their consequences, face risk associated with their actions, influence over their goals, and remain persistent and resourcefulness to achieve high performance (Spreitzer 1995, 2008). From the four dimensions of psychological empowerment, meaning and self-determination are found related with performance of employees at organizations (Shalley and Gilson 2004, Humphrey et al. 2007) based on the theory of job characteristics (Hackman and Oldham 1980). Team level psychological empowerment enhances the feeling of caring about the task (meaning), competence (self-efficacy), potency (self-determination), and influence on outcomes (impact) (Spreitzer 1995). Previous researchers found the competency and impact beliefs are related to the performance of employees due to the enhancement of increased task involvement and persistence (Bandura and Locke 2003).

Theory of psychological empowerment says that employees who feel psychological empowerment in all dimensions take active orientation towards work performance (Spreitzer 2008). Enhanced sense of meaning and impact are also related to higher performance at organizations by enhancing the sense of identification and involvement among employees. Integral to psychological empowerment is to the liberalization of hidden talent and possible attributes of employees to benefit teams and organizations (Block 1987). Intrinsic motivation is central to employee creativity (Amabile 1988), meaning and self-determination are central to psychological empowerment which is intrinsic motivation part of the psychological empowerment of employees. These feelings are also likely to affect competence and self-determination dimensions of psychological empowerment which may further relate to the generation of raw ideas which are novel and useful in nature at organizations (Amabile et al. 2004). Therefore, we expected that team level psychological empowerment would be positively related to team creativity. Formally:

Hypothesis 4: Team psychological empowerment positively relate to team level creativity.

\subsection{Relationship between empowering leadership behavior and team level creativity}

We suggested here that empowering leadership behavior positively relate to team learning behavior and psychological empowerment which are further related to group level creativity at organizations. Based on our previous discussion we are in a position to suppose that empowering leadership behavior also holds direct effect on group level creativity. That is team learning behavior and psychological empowerment mediates the positive relationship between empowering behavior of leaders and creativity of employees at team levels. Previous researchers suggested that empowering behavior of leaders are beneficial for team level performance because it encourages team members to take initiatives, enhance work speed response, and also enhance the value of organizational life within work teams (Cohen et al. 1997). Researchers also found that the relationship between behaviors of leaders to empower their subordinates for team performance is mediated by the psychological empowerment of employees (Kirkman and Rosen 1999).

Hypothesis 5: The relationship between empoweringleadership behavior and team creativity is mediated partially by team level learning behavior and psychological empowerment.

\section{Research methodology}

\subsection{Sample and data collection}

For this study, we collected data from employees of a private commercial bank operating in Pakistan. Human resources management department of the bank coordinated the whole data collection process. One officer from Human resources management department coordinated this data collection process, with help of that officer the researchers identified branch offices with multiple teams 
and 5-9 team members per team. After identifying the researchers randomly selected (Muller et al. 2005, George and Zhou 2001, 2002) 67 teams for the data collection, for further identification and secrecy of data the researchers assigned dummy codes to teams, team members, and team supervisors (Carnabuci and Diószegi 2015, Zhou and George 2003). Human resources coordinator then tagged relevant questionnaire to the relevant persons. Response for supervisors and subordinates were separately tagged to all of the 421 subordinates and their respective 67 supervisors. The researchers asked the respondents to provide their individual responsibility for all the questionnaires tagged with their IDs. Data were collected in two phases; the researchers temporally divided data collection process into different points in time.

After the researchers received a response from 397 subordinates, the researchers then approached their respective supervisors after 2 weeks of their subordinates' response. Two sources of data were used so that any chances of common method bias can be eliminated. The researchers with help of HR coordinator tagged subordinates' IDs with empowering leadership (EL), Team learning behavior (TLB), and Team psychological empowerment (TPE), and supervisors' IDs with Team creativity (TC). Subordinates provided their independent individual responsibility for the measures tagged with their IDs and supervisors also provided their individual independent responsibility for the creativity of the team.

In order to deal with data for missing value cases, the researchers preferred maximum likelihood method instead of other alternatives like list-wise deletion, pairwise deletion, mean replacement, or multiple imputation methods (Chen and Klimoski 2003, Jung and Sosik 2002) available in the literature. The researchers then deleted data with missing cases and mismatched with the response of supervisors (Carnabuci and Diószegi 2015, Muller et al. 2005), which yielded a final sample of employees to 343 with a final response rate of $81 \%$ for subordinates' sample, and all 67 supervisors for supervisors' sample. The final sample of 343 subordinates and 67 supervisors was used in all simple, direct, indirect, and mediated analysis of this research. In final sample which was used in all analyses, $47.34 \%$ were women and 52.66 were men; average age of subordinates was 39.45 years; average of total experience of banking industry was 10.24 years; average experience of working in current workgroup was 3.54 years; $23.5 \%$ held a bachelor degree, $71.5 \%$ were master degree holders, and 5 percent were in the category of other education.

\subsection{Measures}

Empowering Leadership: Empowering leadership was measured using 14-items, 7 points Likert-type scales (Kirkman and Rosen 1999). A sample item is "My immediate supervisor uses my suggestions and ideas when making decisions." All employees working under the supervision of any supervisor will report the empowering leadership behavior of that specific supervisor $(\alpha=.89)$.

Team Creativity: Managers' ratings are most commonly used to measure creativity in field studies (George and Zhou 2001, 2002, Oldham and Cummings 1996). In this research, researchers used team level creativity of employees of multiple teams working at different offices of the bank. Team creativity is measured using 4-items, 5 points Likert-type scale (Janssen 2001). A sample item is "How creative do you consider your team to be?" supervisors will rank their respective team on this scale $(\alpha=.95)$.

Team Learning Behavior: This research used already developed 7 -items, 7 points Likert-type scale (Edmondson 1999), to measure team learning behavior. This scale is most commonly and a widely used measure of management research (Spreitzer 2008). A sample item for this measure is "On this team, someone always makes sure that this research stops to reflect on the team's work processes" $(\alpha=.92)$.

Psychological Empowerment: Psychological empowerment was measured using aggregate method of individual psychological empowerment scale of Spreitzer (1995). This technique has been used previously to measure team level psychological empowerment (Chen and Klimoski 2003, Jung and Sosik 2002). A seven-point, 12-items Likert type scale was used by the researchers to measure psychological empowerment of the teams at organizations (Spreitzer 1995). Sample items are "I have control over what happens in my department" and "I have significant autonomy in determining how I do my job". Employees indicated their individual response on this scale ranging from $1=$ strongly disagree to $7=$ strongly agree (Spreitzer 1995) $(\alpha=.87)$.

Control Variables: Management scholars found that personal sources of power which relate to formal learning and experience affect the generation of novel and useful ideas (Ibarra 1993). Following recommendations of these researchers and also followed the trend in creativity research to use demographic variables as sources of personal power (Shalley et al. 2004, Zhou and George 2003), demographic variables are used as control variables. Data for control variables gender, education, total job experience, and total experience with current team or work units were collected on a self-reporting measure of subordinates. Formal education, total working experience, and experience while working with the current team had already been used as control variables (e.g., Chen et al. 2015, Venkataramani et al. 2016, Perry-Smith 2014). Although, these researchers did not recommend gender as a source of personal power, the researchers also control for gender due to the heterogeneity in the workgroups. 


\section{Results}

\subsection{Preliminary analyses}

Before testing hypotheses of our study, confirmatory factor analysis performed to confirm the validity and statistical discriminate among the key variables using Mplus 7.0, which showed that each variable of our study represents a separate construct. Subscales of psychological empowerment: meaningfulness, competencies, self-determination, and impact served as indicators of the latent construct. For the model fit indicators, Value of $\chi^{2}$ should be signed with a p-value $<.01$ or .05 , values of CFI and TLI should not be less than 0.96, and RMSEA value should not be higher than 0.05 . This study also found best fit for the overall construct of psychological empowerment with a model fit $\chi^{2}=$ $10619.768,819, \mathrm{~N}=343, \mathrm{p}<.01, \mathrm{CFI}=0.96$, TLI 0.97 , and RMSEA $=0.01$ indicated a good fit of model to the data. Cronbach alpha as a lower bound estimate of the reliability of a psychometric test also performed. The results of Cronbach alpha are shown with every measure in the measures section of this research. Descriptive statistics with mean, standard deviation, and Pearson correlations among all the variables of this study are presented in Table 1.

\subsection{Test of hypotheses}

The base of our hypothesized model is a mediation model, this research used three-step procedures to measure the mediation of both team learning behavior and team psychological empowerment independently and collectively on the relationship between empowering leadership behavior and team creativity at organizations (Baron and Kenny 1986). As outlined by these researchers, first, the IV (Independent Variable) must be significant with mediator variables, second, the IV (Independent Variable) must be significant with DV (Dependent variables), and finally, in the presence of independent variable, the mediating variables must be significant with dependent variable (Baron and Kenny 1986). If all of these conditions stand true then this research further check for partial or full mediation of the variables. If in the third condition of mediation model, the independent variable reduces its magnitude or remains significant then is a partial mediation otherwise it is a case of full mediation. Following this three-step procedure, the researchers regressed all the variables as outlined above and present the results in Table 2, 3, and 4. First, the researchers regressed the mediating variables (Team learning behavior and Team psychological empowerment) on independent variable (Empowering leadership) independently and collectively as present the results of the regression in Table 2.

Empowering leadership was significant with both team level learning behavior and psychological empowerment of teams, in this table there are three section, first the researchers regressed team learning behavior on empowering leadership, after that the researchers regressed team psychological empowerment on empowering leadership, and finally the researchers regressed both mediators collectively on independent variable, estimates and standard errors for all of the control variables excluded from the final tables.

With results shown in this Table 2, the researchers fulfilled the first requirement of a mediation model. With the first requirement of this mediation model, the researchers also provided support for hypothesis 1 and hypothesis 2 of this study. As a second step in mediation model, then the researchers regressed the DV on IV, the researchers regressed team creativity on empowering leadership behavior.

Results of this regression are presented in Table 3 of this research, as shown in Table 3, empowering leadership was significant with team creativity, with this significant result, as not hypothesized, the researchers fulfilled the second condition in the model for the mediation. The researchers then regressed the DV on the mediator variables independently and collectively to see the difference in result in presence of another mediator and independent variable. The results are presented in Table 4, the researchers

Table 1. Descriptive statistics with Zero order correlation among the study variables

\begin{tabular}{|l|c|c|c|c|c|c|c|c|c|}
\hline \multicolumn{1}{|c|}{ Variable } & Mean & SD & 1 & 2 & 3 & 4 & 5 & 6 & 7 \\
\hline 1. Gender & 0.72 & 0.37 & & & & & & & \\
\hline 2. Education & 2.87 & 0.65 & -0.013 & & & & & & \\
\hline 3. Total Job Experience & 10.24 & 3.65 & $0.125^{*}$ & 0.031 & & & & & \\
\hline 4. Total Team Experience & 3.54 & 0.23 & $0.043^{*}$ & 0.241 & $-0.146^{*}$ & & & & \\
\hline 5. Empowering Leadership & 4.65 & 1.46 & 0.060 & -0.06 & 0.272 & 0.260 & & & \\
\hline 6. Team Learning Behavior & 4.78 & 1.37 & -0.296 & 0.204 & -0.260 & -0.17 & $0.321^{* *}$ & & \\
\hline $\begin{array}{l}\text { 7. Team Psychological } \\
\text { Empowerment }\end{array}$ & 4.32 & 1.43 & -0.075 & 0.323 & $0.397^{* *}$ & 0.065 & $0.313^{*}$ & $0.197^{*}$ & \\
\hline 8. Team Creativity & 3.47 & 1.22 & -0.061 & -0.08 & $0.156^{*}$ & -0.18 & $0.165^{* *}$ & $0.234^{* *}$ & $0.439^{* *}$ \\
\hline
\end{tabular}

Note: $\mathrm{N}=343.0$ = Female, 1 = Male. For Education, 1 = College Graduate, 2 = Bachelor Degree, 3 = Postgraduate Degree, $4=$ Others. Total Banking Experience and Current Team Experience were measured in years.

${ }^{*} \mathrm{p}<.05 .{ }^{* *} \mathrm{p}<.01$ 
Table 2. Mediators regressed on independent variables

\begin{tabular}{|l|c|c|c|c|}
\hline \multicolumn{1}{|c|}{ Mediators and Variables } & $\chi^{2}(\mathrm{df})$ & Adjusted $\mathrm{R}^{2}$ & Estimate & S.E. \\
\hline Mediator: Team Learning Behavior & $104.30(11)^{\star *}$ & 0.030 & & $0.409^{* *}$ \\
\hline Empowering Leadership & & & & 0.057 \\
\hline Mediator: Team Psychological Empowerment & $107.02(11)^{\star *}$ & 0.175 & $0.253^{\star *}$ & 0.052 \\
\hline Empowering Leadership & & & \\
\hline $\begin{array}{l}\text { Mediator: Team Learning Behavior } \\
\text { Team Psychological Empowerment }\end{array}$ & $221.25(11)^{\star}$ & 0.324 & $0.474^{\star *}$ & 0.051 \\
\hline Empowering Leadership & & & & \\
\hline
\end{tabular}

Note: $\mathrm{N}=343$. S. $\mathrm{E} .=$ standard error. $\chi^{2}=$ chi-square test of model fit. $\mathrm{df}=$ degree of freedom

${ }^{\star} \mathrm{p}<.05 .{ }^{* *} \mathrm{p}<.01$

Table 3. Dependent variables regressed on independent variable

\begin{tabular}{|l|c|c|c|c|}
\hline \multicolumn{1}{|c|}{ Mediators and Variables } & $\chi^{2}(\mathrm{df})$ & Adjusted $\mathrm{R}^{2}$ & Estimate & S.E. \\
\hline Dependent Variable: Team Creativity & $173.162(9)^{\star *}$ & 0.032 & & \\
\hline Empowering Leadership & & & $0.421^{\star *}$ & 0.045 \\
\hline
\end{tabular}

Note: $\mathrm{N}=343$. S.E. $=$ standard error. $\chi^{2}=$ chi-square test of model fit. $\mathrm{df}=$ degree of freedom

${ }^{*} \mathrm{p}<.05 .{ }^{* *} \mathrm{p}<.01$

regressed team creativity on team level learning behavior and psychological empowerment of teams in presence of empowering leadership, first the researchers checked whether the dependent variable is significant with mediating variable or not and then the researchers checked for partial or full mediation for the mediating variables. The researchers found that team learning behavior and team psychological empowerment both were significant independently with team creativity, fulfilling the requirement to support hypothesis 3 and hypothesis 4 of this study; the researchers also checked the significance of both mediators one by one in presences of other. Both mediators showed significant coefficient in absence and presence of another mediator, the results of this regression further strengthened the already proved hypothesis 3 and hypothesis 4 of this research.
Finally, the researchers checked the mediator for partial or full mediation, as shown in Table 4, the coefficient of the empowering leadership on team creativity remained significant with team creativity but reduced it magnitude independently and in presence of another mediator, these results indicated a partial mediation of team learning behavior and psychological empowerment at team level for the relationship between empowering leadership behavior and team level creativity, in an independent check of mediator analysis on the relationship between empowering behavior of the leadership and team creativity, we found support for final hypothesis 5 of this study, in a collective mediation check the coefficient of empowering leadership for team creativity remained significant but reduced its magnitude, with these results the researchers again strengthened the already proved hypothesis 5 of this study. Thus, fulfilled all

Table 4. Depend variables regressed on mediators (independent variables included)

\begin{tabular}{|l|c|c|c|c|}
\hline \multicolumn{1}{|c|}{ Mediators and Variables } & $\chi^{2}(\mathrm{df})$ & Adjusted $\mathrm{R}^{2}$ & Estimate & S.E. \\
\hline Dependent Variable: Team Creativity & $232.809(7)^{* *}$ & 0.185 & & $0.106^{* *}$ \\
\hline Empowering Leadership & & & $0.013^{*}$ & 0.057 \\
\hline Team Learning Behavior & & & & \\
\hline Dependent Variable: Team Creativity & $253.605(7)^{* *}$ & 0.039 & & $0.189^{* *}$ \\
\hline Empowering Leadership & & & $0.107^{*}$ & 0.058 \\
\hline Team Psychological Empowerment & & & & 0.067 \\
\hline Dependent Variable: Team Creativity & $354.235(5)^{* *}$ & 0.099 & $0.228^{* *}$ & 0.054 \\
\hline Empowering Leadership & & & $0.133^{*}$ & 0.058 \\
\hline Team Learning Behavior & & & $0.232^{*}$ & 0.071 \\
\hline Team Psychological Empowerment & & & & \\
\hline
\end{tabular}

Note: $\mathrm{N}=343$. S.E. $=$ standard error. $\chi^{2}=$ chi-square test of model fit. $\mathrm{df}=$ degree of freedom

${ }^{*} \mathrm{p}<.05 .{ }^{* *} \mathrm{p}<.01$ 
the requirements of the mediation model and found support for all hypothesis of this study. The researchers also performed bootstrapping to check the confidence on the mediation with a confidence interval of 5000 for the mediation test with bootstrapping. The results replicated when the researchers used bootstrapping with a confidence interval of 5000. Thus, proving the mediating roles team learning behavior and team psychological empowerment plays between empowering leadership and team creativity.

In order to check the patter of mediation, the researchers further examined all case of the analysis one by one independently to show how all of these conditions proved in the analyses presented in Tables 4 and 5. As shown in table number 4 above, empowering behavior of the leadership was significant with creativity at team level in all of three analyses $(\beta=0.106, \mathrm{p}<.01, \beta=0.189, \mathrm{p}<.01, \beta=0.228$, $\mathrm{p}<.01$ ) all the $\mathrm{p}$ values for $\beta$ are less than .01 indicating ruling out the possibility of full mediation in all of the cases. Therefore, the researchers have partial mediation of team learning behavior and team psychological empowerment for the relation of empowering leadership behavior and creativity at team levels.

This partial mediation existed in the path empowering leadership —» team learning behavior —» team creativity $(\beta=0.013, \mathrm{p}<.05)$ and empowering leadership $\longrightarrow$ - team psychological empowerment —» team creativity $(\beta=0.107$, $\mathrm{p}<.05$ ). In both of these cases, the $\mathrm{p}$ value is less than .05 which indicated mediation. Despite lack of full mediation for the relationships, empowering leadership showed a strong impact on team creativity. Thus, the researchers conclude here that team learning behavior and team psychological empowerment as team process also the researchers used here the team emergent state along with empowering behavior of the leadership made significant contributions in explaining the team creativity.

\section{Theoretical contributions}

From the result of our study, a number of theoretical contributions could be derived. The most important implication for the theory is investigating the direct relationship of empowering leadership on team creativity (Liden et al. 2000).
Empowering leadership is a form of structural empowering which was long conceptualized as having effect on performance-related outcomes on both individual and team levels (Liden et al. 2000), but team level investigations are very limited to empirically prove the relationship between empowering leadership as structural empowering behavior of leaders to their subordinates, although, researchers have investigated the relationship between the structural empowerment dimensions and performance of the employee. But an explicit effort for investigating empowering leadership as structural empowerment for the team level creativity of the employees as the researchers did in our investigation, by doing so this research extended previous research on investigating the role of structural empowering behavior for performance-related outcome of the employees (Chang and Chuang 2011, Akgün et al. 2007, Langfred 2007).

Additionally, our results are also consistent with the findings of previous researchers that structural empowerment dimensions affect significantly the performance-related outcomes of the employees. This research investigated creativity of employees at the team level as an important indicator of the performance of employees in contemporary organizations (Hirst et al. 2009, Langfred 2007, Ahearn et al. 2004). Creativity is an important property of performance for the survival and existence of organizations in this contemporary dynamic environment. This research captured the recent trend in management studies by investigating creativity of teams as an important determinant of performance. This research also captured the recent trend in investigating the creativity of employees from the more social and structural dimensions (Shalley et al. 2004). Investigating structural dimension for team level creativity of employees is also consistent with the recent trend in creativity literature (e.g., Carnabuci and Diószegi 2015, Chen et al. 2015, Venkataramani et al. 2016, Perry-Smith 2014).

By investigating these important contemporary trends, this research also contributed to creating literature with the results of our investigation. Our results of this research revealed that empowering leadership as a structural property of structural dimension of empowerment is related with team level creativity; our results also revealed that the structural dimensions which are related to improving the

Table 5. Pattern of direct and indirect effects

\begin{tabular}{|l|l|l|l|l|}
\hline \multicolumn{1}{|c|}{ Observed Variable } & \multicolumn{1}{|c|}{ Mediator } & Effect type & \multicolumn{1}{c|}{ Significant value } & \multicolumn{1}{c|}{ Hypothesis Supported } \\
\hline Team Learning Behavior & & Direct & $\beta=0.409, \mathrm{p}<.01$ & Hypothesis 1 \\
\hline $\begin{array}{l}\text { Team Psychological } \\
\text { Empowerment }\end{array}$ & Direct & $\beta=0.253, \mathrm{p}<.01$ & Hypothesis 2 \\
\hline Team Creativity & Direct & $\beta=0.013, \mathrm{p}<.05$ & Hypothesis 3 \\
\hline Team Creativity & Direct & $\beta=0.107, \mathrm{p}<.05$ & Hypothesis 4 \\
\hline Team Creativity & $\begin{array}{l}\text { Team Psychological Empowerment } \\
\text { Team Learning Behavior }\end{array}$ & Indirect & $\begin{array}{l}\beta=0.107, \mathrm{p}<.05 \\
\beta=0.013, \mathrm{p}<.05\end{array}$ & Hypothesis 5 \\
\hline
\end{tabular}


perceptions of the employees for the structural level empowerment affect the creativity of employees. These structural properties affect directly the team level creativity of the employees and indirectly by affecting the team learning behavior and team level psychological empowerment of the employees. As a direct path structural empowering leadership behavior provided the resources needed for the creativity of employees and as an indirect path empowering leadership flourished the overall learning environment in the teams and also affected the overall psychological empowerment of teams for creativity. The results uniquely explained and contribute the literature on team level creativity of employees by focusing the considerable variance which empowering leadership had on team learning behavior and team psychological empowerment for team level creativity of the employees.

Finally, leader's role was conceptualized and found to affect the creativity of employees (e.g., Chen et al. 2015, Carnabuci and Diószegi 2015). This leadership behavior is closely related to recent trend at organizations in empowering their workforce to enhance their performance (Lawler et al. 2001). the purpose of this line of research remained with understating two important aspects here, one leaders role in sharing his/ her authority and independence of employees (Lawler et al. 2001) and on the other end, subordinates' response towards this empowerment behavior (Chen et al. 2015, Carnabuci and Diószegi 2015, Ohly et al. 2010) but in these research lines, these two perspectives have been investigated independently, investigating both lines of research in one investigation is very rare (e.g., Srivastava et al. 2006). This research tried to investigate these relationships in a single study, more specifically this research investigated leaders' empowering behavior and employee's response towards these empowerment behaviors in a single investigation which have rarely been investigated previously (Srivastava et al. 2006). By doing so, this research contributes to empowerment literature which was previously lacking support from such collective investigations.

\subsection{Practical contributions}

Researchers investigated empowering leadership behavior for performance-related outcomes. But in previous investigations, researchers used student samples to investigate these important relationships (e.g., Burris 2012, Erdogan and Bauer 2009, Ergeneli et al. 2007, Harris et al. 2009), causing a need for empirical support to most of the research on empowering leadership and performance-related outcomes of the employees from the perspectives of real-life work teams. Therefore, it was important to investigate the relationship between these important relationships from the perspectives of real-life work teams. Also, the researchers who previously used employee sample mainly focused employees of lower hierarchical level as their sample (e.g.,
Burris 2012, Erdogan \& Bauer 2009, Harris et al. 2009). However, at organizations, employees with different hierarchical levels perform a different task which affects their way of thinking, their response to empowerment, their learning behavior, their psychological states, and their performance (Finkelstein and Hambrick 1997). These work units are composed for larger span of time with diversified controlling formal and informal tasks and responsibilities, these higher hierarchical level teams perform critical and important controlling tasks for their organizations (Finkelstein and Hambrick 1997), therefore, the findings of lower hierarchical level employees cannot be generalized employees of the teams who perform and operate at higher hierarchical levels (Cohen and Bailey 1997).

Therefore, this research cannot directly generalize the previous findings to all hierarchical level employees of the organizations. Our selection and investigation of managerial level employees for the investigation of structural empowerment, psychological empowerment, team learning behavior, and creativity of the employees was significantly critical and worthwhile. Management level sample provided highly worthwhile practical implications. This research further contributed to the management research by investigating the underlying mechanism of team overall learning behavior and team psychological empowerment for the creativity of the employees due to the structural empowerment initiatives which organizations take to increase the productivity of their employees. Consistent with other researchers we also found support the argument that the organizational initiatives which relate with empowerment of the employees enhance performance related outcomes and desirable work attitude (e.g., Hempel et al. 2012, Staw and Epstein 2000), consistent with this line of research, the researchers also recommend organizations, if they want to enhance creativity of their employee collectively, then like other initiative they take to enhance the creativity, they should also implement the empowerment supportive structure along with fostering an environment of mutual learning and psychological empowerment perception for the enhanced creativity of the employees. Socio-political structure affects the creativity of the employees at organizations (Spreitzer 2008), by affecting the psychological dimensions of empowerment, which may further relate to desired organizational outcomes in form of contextual and behavioral performance of employees as need by organizations.

\subsection{Limitations and future research directions}

Although, the researchers investigated empowering leadership, team learning behavior, and team psychological empowerment for creativity as a collective behavioral performance of the employees. To eliminate the chances of common method biases, the researchers collected data from two different sources by temporally dividing data 
collection process into three points in time. These two conservative steps reduced our sample from 421 to 343 with a final rate of $81 \%$ response from the employees. With our empirical findings the researchers also contributed to both academia and practitioners and made some distinctive contributions but this investigation should also be seen with its limitations. First, although the researchers have strong theoretical reason to expect that empowering leadership would precede learning behavior of the teams and psychological empowerment of the teams, also learning the behavior of the teams and psychological empowerment of the teams would precede team creativity but the possibility of reverse causation cannot be ruled out directly. Due to the cross-sectional research design of our research, the researchers were not able to confirm the reverse causation effect of variables if existed. The researchers cannot firmly say that the common perception that empowering leadership would precede team learning behavior and team psychological empowerment, also team learning behavior and team psychological empowerment would precede the team level creativity at organizations.

There is also a possibility that the employees with creativity as teams also affect their learning behavior and also their collective thinking of psychological empowerment. Similarly, there is also a possibility that the team with more psychological empowerment affect the behavior of leaders for their empowering behavior also teams with learning behavior provoke empowering leadership behavior at organizations. There is also another possibility that psychological empowerment is a construct with four integral dimensions: meaningfulness, individual competence, self-determination, and impact. There is also a possibility that these four integral dimensions which define psychological empowerment as a single measure, are being affected by the team level creativity and also provoke the empowering leadership behavior at organizations. Also, there can be another explanation that teams with more creative output claim to be high in learning and high in psychological empowerment. Therefore, for all this, the researchers recommend a longitudinal study to investigate these relationships for firm evidence and reliability on the results. The researchers investigated employees of a banking sector, the reason to choose that specific organization and not others are that first, this specific organization was in our approach, it was easy for us to collect data from that organization, and second and more important is that this bank had already implemented organization-wide initiatives to enhance creativity of the employees, therefore, that organization best suited the objectives of our study. Therefore, further research should use sector other than the financial sector as the researchers choose to collect data and to measure our hypothesized model. The researchers recommend an investigation with data collected from other than financial sector will bring a more dynamic picture of the hypothesized relationships.

\section{Conclusions}

In creativity research focus of researchers remained with understanding leaders' behavior for the individual level creative output of the employees. In this research, the researchers tried to investigate the empowering leadership as an important leaders' behavior for team level creativity of the employees through the mechanism of team learning behavior and team psychological empowerment as team emergent states and team process. With results of this research, the researchers showed that empowering leadership affects the creativity of employees as a team. Leaders' empowering behavior also affect the underlying mechanism of team learning behavior and team psychological empowerment which further effects the team level creativity of the employees. Our results revealed important insight into the relationship of empowering leadership behavior, team learning behavior, team psychological empowerment, and team creativity. Further research on the interactive effect of team process and team emergent state for team level creativity of employees will be a fruitful area of future research.

\section{References}

Ahearn KK, Ferris GR, Hochwarter WA, Douglas C, Ammeter AP (2004) Leader political skill and team performance. Journal of Management 30 (3): 309-327. https://doi.org/10.1016\%2Fj. jm.2003.01.004

Akgün AE, Keskin H, Byrne JC, Aren S (2007) Emotional and learning capability and their impact on product innovativeness and firm performance. Technovation 27 (9): 501-513. https:// doi.org/10.1016/j.technovation.2007.03.001

Amabile TM (1996) Creativity in context. Boulder, CO: Westview Press.

Amabile T, Fisher CM, Pillemer J (2014) IDEO's culture of helping. Harvard Business Review 92, nos. 1-2 (JanuaryFebruary 2014): 54-61.

Amabile TM (1988) A model of creativity and innovation in organizations. Research in organizational behavior 10 (1): 123-167.

Amabile TM, Schatzel EA, Moneta GB, Kramer SJ (2004) Leader behaviors and the work environment for creativity: perceived leader support. The Leadership Quarterly 15 (1): 5-32. https:// doi.org/10.1016/j.leaqua.2003.12.003

Aryee S, Chen ZX (2006) Leader-member exchange in a chinese context: antecedents, the mediating role of psychological empowerment and outcomes. Journal of Business Research 59 (7): 793-801. https://doi.org/10.1016/j.jbusres.2005.03.003

Bandura A (1997) Self-efficacy: the exercise of control: New York: Freeman.

Bandura A, Locke EA (2003) Negative self-efficacy and goal effects revisited. Journal of applied psychology 88 (1): 87-99. https:// doi.org/10.1037/0021-9010.88.1.87 
Baron RM, Kenny DA (1986) The moderator-mediator variable distinction in social psychological research: conceptual, strategic, and statistical considerations. Journal of personality and social psychology 51 (6): 1173-1182. https://doi. org/10.1037/0022-3514.51.6.1173

Block P (1987) The empowered manager: positive political skills at work. Jossey-Bass.

Bunderson JS, Sutcliffe KM (2003) Management team learning orientation and business unit performance. Journal of Applied Psychology 88 (3): 552-560. https://doi.org/10.1037/00219010.88.3.552

Burris ER (2012) The risks and rewards of speaking up: managerial responses to employee voice. Academy of Management Journal 55 (4): 851-875. https://doi.org/10.5465/amj.2010.0562

Carnabuci G, Diószegi B (2015) Social networks, cognitive style, and innovative performance: a contingency perspective. Academy of Management Journal 58 (3): 881-905. https:// doi.org/10.5465/amj.2013.1042

Chang HH, Chuang S-S (2011) Social capital and individual motivations on knowledge sharing: Participant involvement as a moderator. Information \& management 48 (1): 9-18. https:// doi.org/10.1016/j.im.2010.11.001

Chamberlin M, Newton DW, LePine JA (2018) A meta-analysis of empowerment and voice as transmitters of high-performance managerial practices to job performance. Journal of Organizational Behavior 2018: 1-18 https://doi.org/10.1002/job.2295

Chen G, Klimoski RJ (2003) The impact of expectations on newcomer performance in teams as mediated by work characteristics, social exchanges, and empowerment. Academy of Management Journal 46 (5): 591-607. http://doi. org/10.5465/30040651

Chen MH, Chang YY, Chang YC (2015) Entrepreneurial orientation, social networks, and creative performance: middle managers as corporate entrepreneurs. Creativity and Innovation Management 24 (3): 493-507. https://doi.org/10.1111/ caim. 12108

Chow IHS (2018) The mechanism underlying the empowering leadership-creativity relationship. Leadership \& Organization Development Journal 39 (2): 202-217. https://doi.org/10.1108/ LODJ-03-2016-0060

Cho HJ, Pucik V (2005) Relationship between innovativeness, quality, growth, profitability, and market value. Strategic management journal 26 (6): 555-575. https://doi.org/10.1002/ smj.461

Cohen SG, Bailey DE (1997) What makes teams work: group effectiveness research from the shop floor to the executive suite. Journal of management 23 (3): 239-290. https://doi. org/10.1016/S0149-2063(97)90034-9

Cohen SG, Chang L, Ledford GE (1997) A hierarchical construct of self-management leadership and its relationship to quality of work life and perceived work group effectiveness. Personnel Psychology 50 (2): 275-308. https://doi. org/10.1111/j.1744-6570.1997.tb00909.x

Conger JA, Kanungo RN (1988) The empowerment process: integrating theory and practice. Academy of management review 13 (3): 471-482. https://doi.org/10.5465/amr.1988.4306983

D'Innocenzo L, Mathieu JE, Kukenberger MR (2016) A meta-analysis of different forms of shared leadership-team performance relations. Journal of Management 42 (7): 19641991. https://doi.org/10.1177/0149206314525205

DeConinck J, DeConinck MB (2017) The relationship between servant leadership, perceived organizational support, performance, and turnover among business to business salespeople. Archives of Business Research 5 (10): 57-71. https://doi. org/10.14738/abr.510.3730

Druskat VU, Wheeler JV (2003) Managing from the boundary: the effective leadership of self-managing work teams. Academy of Management Journal 46 (4): 435-457. https://doi. org/10.5465/30040637

Dvir T, Eden D, Avolio BJ, Shamir B (2002) Impact of transformational leadership on follower development and performance: a field experiment. Academy of management journal 45 (4): 735-744. https://doi.org/10.5465/3069307

Dong Y, Bartol KM, Zhang ZX, Li C (2017) Enhancing employee creativity via individual skill development and team knowledge sharing: Influences of dual-focused transformational leadership. Journal of Organizational Behavior 38 (3): 439458. https://doi.org/10.1002/job.2134

Edmondson A (1999) Psychological safety and learning behavior in work teams. Administrative science quarterly 44 (2): 350383. https://doi.org/10.2307/2666999

Erdogan B, Bauer TN (2009) Perceived overqualification and its outcomes: the moderating role of empowerment. Journal of applied psychology 94 (2): 557-565. https://doi.org/10.1037/ a0013528

Erdogan B, Bauer TN, Taylor S (2015) Management commitment to the ecological environment and employees: implications for employee attitudes and citizenship behaviors. Human Relations 68 (1): 1669-1691. https://doi.org/10.1177/ 0018726714565723

Ergeneli A, Arı GSl, Metin S (2007) Psychological empowerment and its relationship to trust in immediate managers. Journal of Business Research 60 (1): 41-49. https://doi.org/10.1016/j. jbusres.2006.09.012

Finkelstein S, Hambrick DC (1997) Strategic leadership: top executives and their effects on organizations. Donaldson Reviews Finkelstein and Hambrick 22 (2): 221224. South-Western Publishing Company. https://doi. org/10.1177/031289629702200205

George JM, Zhou J (2001) When openness to experience and conscientiousness are related to creative behavior: an interactional approach. Journal of applied psychology 86 (3): 513-524. https://doi.org/10.1037/0021-9010.86.3.513

George JM, Zhou J (2002) Understanding when bad moods foster creativity and good ones don't: the role of context and clarity of feelings. Journal of Applied Psychology 87 (4): 687-697. https://doi.org/10.1037/0021-9010.87.4.687

Granovetter M, Marsden P, Lin N (1982) Social structure and network analysis. The Network Construction of Individuals and Groups. Political Science 572/ Sociology 585.

Hackman JR, Oldham GR (1980) Work redesign. MA: AddisonWesley. https://doi.org/10.1177/105960118200700110

Harris KJ, Wheeler AR, Kacmar KM (2009) Leader-member exchange and empowerment: direct and interactive effects on job satisfaction, turnover intentions, and performance. The Leadership Quarterly 20 (3): 371-382. https://doi. org/10.1016/j.leaqua.2009.03.006 
Hechanova-Alampay R, Beehr TA (2001) Empowerment, span of control, and safety performance in work teams after workforce reduction. Journal of Occupational Health Psychology 6 (4): 275-282. https://doi.org/10.1037/1076-8998.6.4.275

Hempel PS, Zhang Z-X, Han Y (2012) Team empowerment and the organizational context decentralization and the contrasting effects of formalization. Journal of Management 38 (2): 475-501. https://doi.org/10.1177/0149206309342891

Hirst G, Van Knippenberg D, Zhou J (2009) A cross-level perspective on employee creativity: goal orientation, team learning behavior, and individual creativity. Academy of Management Journal 52 (2): 280-293. https://doi.org/10.5465/ amj.2009.37308035

House RJ, Dessler G (1975) The path-goal theory of leadership. Journal of Contemporary Business 3: 81-97.

Humphrey SE, Nahrgang JD, Morgeson FP (2007) Integrating motivational, social, and contextual work design features: a meta-analytic summary and theoretical extension of the work design literature. Journal of Applied Psychology 92 (5): 1332-1356. https://doi.org/10.1037/0021-9010.92.5.1332

Ibarra H (1993) Network centrality, power, and innovation involvement: determinants of technical and administrative roles. Academy of Management Journal 36 (3): 471-501. https:// doi.org/10.5465/256589

Isenberg D (1988) Managerial thinking: an inquiring into how senior managers think. Book manuscript.

Janssen O (2001) Fairness perceptions as a moderator in the curvilinear relationships between job demands, and job performance and job satisfaction. Academy of management Journal 44 (5): 1039-1050. https://doi.org/10.5465/3069447

Jung DI, Sosik JJ (2002) Transformational leadership in work groups the role of empowerment, cohesiveness, and collective-efficacy on perceived group performance. Small group research 33 (3): 313-336. https://doi. org/10.1177/10496402033003002

Katz D, Kahn RL (1978) The social psychology of organizations, New York: Wiley, 1978: 1-838.

Kirkman BL, Rosen B (1999) Beyond self-management: antecedents and consequences of team empowerment. Academy of Management Journal 42 (1): 58-74. https://doi. org/10.5465/256874

Knippenberg Dv, Dreu Cd, Homan AC (2004) Work group diversity and group performance: an integrative model and research agenda. Journal of Applied Psychology 89 (6): 1008 1022. https://doi.org/10.1037/0021-9010.89.6.1008

Langfred CW (2007) The downside of self-management: a longitudinal study of the effects tf conflict on trust, autonomy, and task interdependence in self-managing teams. Academy of management Journal 50 (4): 885-900. https://doi.org/10.5465/ amj.2007.26279196

Latham GP, Winters DC, Locke EA (1994) Cognitive and motivational effects of participation: a mediator study. Journal of Organizational Behavior 15 (1): 49-63. https://doi.org/10.1002/ job.4030150106

Lawler EE, Mohrman SA, Benson G (2001) Organizing for high performance: employee involvement, tqm, reengineering, and knowledge management in the fortune 1000. The ceo report: Jossey-Bass, Book.
Liden RC, Wayne SJ, Sparrowe RT (2000) An examination of the mediating role of psychological empowerment on the relations between the job, interpersonal relationships, and work outcomes. Journal of applied psychology 85 (3): 407416. https://doi.org/10.1037/0021-9010.85.3.407

Locke EA, Alavi M, Wagner JA III (1997) Participation in decision making: an information exchange perspective. In G. R. Ferris (Ed) Research in personnel and human resources management 15: 293-331. US: Elsevier Science/JAI Press.

Mathieu JE, Heffner TS, Goodwin GF, Salas E, Cannon-Bowers JA (2000) The influence of shared mental models on team process and performance. Journal of applied psychology 85 (2): 273-283. https://doi.org/10.1037/0021-9010.85.2.273

Mathieu JE, Taylor SR (2006) Clarifying conditions and decision points for mediational type inferences in organizational behavior. Journal of Organizational Behavior 27 (8): 1031-1056. https://doi.org/10.1002/job.406

Mathieu JE, Hollenbeck JR, van Knippenberg D, Ilgen DR (2017) A century of work teams in the journal of applied psychology. Journal of Applied Psychology 102 (3): 452. https://doi. org/10.1037/apl0000128

Mills PK, Ungson GR (2003) Reassessing the limits of structural empowerment: organizational constitution and trust as controls. Academy of management Review 28 (1): 143-153. https://doi.org/10.5465/amr.2003.8925254

Muller D, Judd CM, Yzerbyt VY (2005) When moderation is mediated and mediation is moderated. Journal of personality and social psychology 89 (6): 852-563. https://doi. org/10.1037/0022-3514.89.6.852

Ng TW (2017) Transformational leadership and performance outcomes: analyses of multiple mediation pathways. The Leadership Quarterly 28 (3): 385-417. https://doi.org/10.1016/j. leaqua.2016.11.008

Ohly S, Kase R, Škerlavaj M (2010) Networks for generating and for validating ideas: the social side of creativity. Innovation 12 (1): 41-52. https://doi.org/10.5172/impp.12.1.41

Oldham GR, Cummings A (1996) Employee creativity: personal and contextual factors at work. Academy of management journal 39 (3): 607-634. https://doi.org/10.5465/256657

Perry-Smith JE (2014) Social network ties beyond nonredundancy: an experimental investigation of the effect of knowledge content and tie strength on creativity. Journal of Applied Psychology 99 (5): 831-846. https://doi.org/10.1037/a0036385

Rosenthal T, Zimmerman B (1978) Social learning and cognitionacademic press. New York.

Shalley CE, Gilson LL (2004) What leaders need to know: a review of social and contextual factors that can foster or hinder creativity. The Leadership Quarterly 15 (1):33-53. http://doi. org.10.1016/j.leaqua.2003.12.004

Shalley CE, Zhou J, Oldham GR (2004) The effects of personal and contextual characteristics on creativity: where should we go from here? Journal of management 30 (6): 933-958. https:// doi.org/10.1016/j.jm.2004.06.007

Spreitzer G, Garrett L, Bacevice P (2015) Should your company embrace coworking? MIT Sloan Management Review, Book.

Spreitzer GM (1995) Psychological empowerment in the workplace: dimensions, measurement, and validation. Academy of management Journal 38 (5): 1442-1465. https://doi. org/10.5465/256865 
Spreitzer GM (2008) Taking stock: a review of more than twenty years of research on empowerment at work. Handbook of organizational behavior, 54-72.

Srivastava A, Bartol KM, Locke EA (2006) Empowering leadership in management teams: effects on knowledge sharing, efficacy, and performance. Academy of management Journal 49 (6): 1239-1251. https://doi.org/10.5465/amj.2006.23478718

Stasser G, Titus W (1985) Pooling of unshared information in group decision making: biased information sampling during discussion. Journal of personality and social psychology 48 (6): 1467-1478. https://doi.org/10.1037/0022-3514.48.6.1467

Staw BM, Epstein LD (2000) What bandwagons bring: effects of popular management techniques on corporate performance, reputation, and ceo pay. Administrative Science Quarterly 45 (3): 523-556 https://www.jstor.org/stable/2667108

Subramaniam M, Youndt MA (2005) The influence of intellectual capital on the types of innovative capabilities. Academy of Management Journal 48 (3): 450-463. https://doi.org/10.5465/ amj.2005.17407911

Taggar S (2001) Group composition, creative synergy, and group performance. The Journal of Creative Behavior 35 (4): 261286. https://doi.org/10.1002/j.2162-6057.2001.tb01050.x

Venkataramani V, Zhou L, Wang M, Liao H, Shi J (2016) Social networks and employee voice: The influence of team members' and team leaders' social network positions on employee voice. Organizational Behavior and Human Decision Processes 132: 37-48. https://doi.org/10.1016/j.obhdp.2015.12.001

Van Knippenberg D, De Dreu C, \& Homan A (2004) Work group diversity and group performance: an integrative model and research agenda. Journal of Applied Psychology 89 (6): 10081022. https://doi.org/10.1037/0021-9010.89.6.1008

Wegner DM (1987) Transactive memory: a contemporary analysis of the group mind. In: Mullen B, Goethals GR (Eds) Theories of group behavior. Springer Series in Social Psychology. Springer, New York, NY. https://doi.org/10.1007/978-1-46124634-3_9

Zhang S, Ke X, Frank Wang XH, Liu J (2018) Empowering leadership and employee creativity: a dual-mechanism perspective. Journal of Occupational and Organizational Psychology. Online version/In Press. https://doi.org/10.1111/joop.12219

Zhou J, George JM (2003) Awakening employee creativity: the role of leader emotional intelligence. The leadership quarterly 14 (4): 545-568. https://doi.org/10.1016/S1048-9843(03)00051-1

Zhou J, Shin SJ, Brass DJ, Choi J, Zhang Z-X (2009) Social networks, personal values, and creativity: evidence for curvilinear and interaction effects. Journal of Applied Psychology 94 (6): 1544-1552. https://doi.org/10.1037/a0016285 